\title{
Developing Assessment Rubrics in Pedagogical Content Knowledge for Mathematical Problems
}

\author{
Rini Sulastri ${ }^{1}$, Rahmah Johar ${ }^{2}$, Said Munzir ${ }^{3}$, and M. Duskri ${ }^{4}$ \\ \{rini.sulastri@serambimekkah.ac.id\} \\ ${ }^{1}$ Department of Mathematics Education, Universitas Serambi Mekkah, Aceh, Indonesia \\ ${ }^{2}$ Department of Mathematics Education, Universitas Syiah Kuala, Aceh, Indonesia \\ ${ }^{3}$ Department of Mathematics, Universitas Syiah Kuala, Aceh, Indonesia \\ ${ }^{4}$ Department of Mathematics Education, State Islamic University of Ar-Raniry, Aceh, Indonesia
}

\begin{abstract}
Pedagogical content knowledge is a competence that must be mastered by teachers and also prospective teachers in learning process as ability to assess the students work. In addition, they are also required to learn the international standard problems such as PISA (Programme for International Student Assessment) to be taught to students. Because of incomplete and unclear scoring rubric, especially in answering PISA questions, this study purpose was to develop valid assessment rubrics in pedagogical content knowledge for mathematical problems. Assessment rubrics were rubric for students work in answering PISA questions for most difficult level, and rubric for prospective teachers' ability in assessing students work. Subjects in this study were eight prospective teachers' of Mathematics Education Department, Syiah Kuala University selected by purposive sampling. This development research used Plomps' development model in five phases. The results showed that both rubrics had the valid criteria that consisting of content and construct validity. Content validity was viewed of the suitability of PCK components, and substance and concept for PISA questions with thinking level of junior high school students. Construct validity was viewed of the suitability of aspects at rubrics with concept of PISA questions, and presented analysis aspects were structured as PCK components
\end{abstract}

Keywords: Development, Rubric, Assessment, PCK, PISA

\section{INTRODUCTION}

Along with the development of educational technology, the development of science also went through changes and improvements. Not exception to mathematics education is still felt difficult for some people. This not only happens to the students but also to the teacher who should be able to master the mathematical material appropriately which affects the students' abilities. One of the data obtained from the results of Indonesian student tests at the international level, PISA (Programme for International Student Assessment) for several periods, Indonesia is still in the bottom position. In PISA, there are contextual questions that are used to measure students' literacy abilities aged around 15 years. In addition, the problem 
of PISA is also non routine in reading literacy, matehematics literacy, and science literacy [1][2].

Indonesia was ranked 64th out of 65 participating countries with an average score of mathematics of 375 which is well below the OECD average of 494 in 2012 ([3]; [4]). Especially in a matter of high level in PISA that is level 5 or 6, Indonesia got an average value of 0.3 from the average of OECD 12.6. On the contrary, for the low level below level 2, Indonesia scored very high (75.7) and even far from the average OECD score of 23.1. In 2015 Indonesia's ranking increased to the 62nd position from 70 participants with an average value of increasing although not significant [5]. This means, the ability of Indonesian students is still very low in mathematical problem solving related to the daily or non routine problems. Just for simple problems that can be resolved appropriately. In this case, students' cognitive abilities cause their difficulties in solving mathematical problems as memorized and recalled the fact that related to make a connection [6]. Several students' difficulties in mathematical problem solving are understanding the keywords of problems to mathematical sentences, unable to describe some information in the problem, answering without any thinking process, and do not like to read short or long mathematical problems [7].

In addition to students, teachers also have difficulty in understanding mathematical concepts that are very impact in solving mathematics problems. In this case, prospective teachers still have difficulty in solving and analyzing mathematics problems, especially nonroutine problems such as PISA [8]. Bayrakdar [8] states prospective teachers' difficulties in solving the PISA problems caused their less strategies, so they can not using and adopting in difference points of problems. There is influenced their PCK in learning process later.

Content Knowledge of good teachers, both in mastering the concepts taught as well as material interrelationship with real life issues are very supportive in shaping and influencing students' knowledge and thinking processes. However, this can happen if the pedagogical knowledge of teachers for example in organizing learning is also good. The relationship between PCK-forming components in the conceptual framework of Sorto, et.al [9] is based on theories of teacher preparation, teacher capacity, and teaching practice.

One of PCK aspects of prospective mathematics teachers is the ability in solving non routine mathematics problems as PISA questions. Not only solve it but they can also transfer the knowledge for students and use in learning process. The impact of it, students can be easy to understand and solve PISA questions related problems in their life.

Many solutions to solve PISA problems, one of it is prospective teachers at education program must have and learn more about skills of problem solving as daily life problems related problems in situations and questions [8]. Because the rubric for analyzing PISA answers is not yet available, the purpose of this study was to develop valid assessment rubrics for students work and assessment rubric for prospective teachers' ability in assessing students' work. Assessment rubric for students work was used by prospective teachers to assess the students work in answering questions of PISA for most difficult level, while assessment rubric of prospective teachers' ability was used by researcher in assessing the results of the assessment done by prospective teachers.

\section{Methods}

This type of research is a development research for two assessment rubrics in valid criteria. There is assessment rubric of student's work, and assessment rubric of the ability of 
prospective teachers in assessing student's work. The development follows the phases of the Plomp [10] in development model consisting of five phases: the initial investigative phase, the design phase, the realization/construction phase, the test phase, the evaluation, and the revision, and the implementation phase. However, in the development that is done only until the fourth phase. This is because the phase has been obtained in accordance with the purpose of research is the development of rubrics that meet the valid criteria, consisting of valid contents and valid constructs.

Subjects in this research are seven prospective teachers of International Standard Teacher Education Program (PGBI) at Mathematics Education Department of Syiah Kuala University. Selection of subjects by purposive sampling with the reason the subject is taking the course Teaching Mathematics I (Mathematics Learning Planning). This is because the course requires students to assess the learning outcomes and improve the shortcomings in the learning process. Therefore, subjects are required to assess students' work by suggesting appropriate assistance for students with problems or constraints.

\section{Result and Discussion}

\subsection{Plemenary investigation phase}

In this phase, some real PISA problems in most difficult level (level 5 and level 6) in 2012 and 2009 chosen for using in the first test. After translated, arranged the answer keys, and validated by the experts in mathematical contents, then done tests on junior high school students. The implementation of this test was conducted several times by replacing some of the problems in three different schools, SMPN 1 Banda Aceh, SMPN 9 Banda Aceh, and SMPN 8 Banda Aceh for students of class IX. This is because the expected answers are students' answers containing misconceptions, completion errors, various settlements and strategies used. The goal is the subject of research that students can analyze the student's answers by adjusting the components on the rubric developed. The results of this initial test finally got some student works or answers from three PISA questions that convene the criteria for using in research.

Before determining research subjects of prospective teachers, they were tested with the same problem given to junior high school students. The goal is to know their ability in completing and understanding the problem of PISA before the analysis of the results of student answers. Of the eight students there were only three students who could solve the PISA problem correctly for each question, and there was one student who answered rightly for two PISA questions. Furthermore, these three students will be the subject of research in developing the assessment rubric.

There are two developed rubrics. First rubric is for assessment student's work and prospective teachers in answering and solving PISA problem. In this rubric the assessment components are adapted of PISA components for most difficult level (level 5 and 6). The second rubric is rubric to assess prospective teachers' ability in assessing student work. Both rubrics are also adapted of PCK components associated with the ability to understand and solve problems and assessment of student work. 


\subsection{Design phase}

In this phase, the design is done for both rubrics. The rubric component is adapted to aspects of PISA and PCK concerns. In addition, the rubric component is also adjusted between the assessment rubric for student's work, and the assessment rubric for the prospective teacher's ability in assessing student's work. The rubric design is based on PCK components developed from PCK components according to [11], [12], and [13].

Aspects of PCK assessment contained in the rubric for analyzing student work according to [12] is content knowledge and skill, analysis of student work, and feedback to students. PCK components according to [13] is knowledge of students' (mis)conceptions and difficulties, knowledge of instructional strategies, knowledge of mathematical tasks and cognitive demands, knowledge of educational ends, knowledge of curriculum and media, context knowledge, content knowledge, and pedagogical knowledge.

According to [11] the component of content knowledge assessment in pedagogical context consists of deep understanding of basic mathematics, content to deconstruct key components, mathematical structure and its relationship, procedural capability, and solution method. While the components of pedagogical knowledge assessment in content context are the purpose of learning, gain and maintain student focus, and classroom management techniques.

\subsection{Realization/construction phase}

This phase is an advanced phase of the design of activities to be undertaken. In this phase, developed the draft rubric is adjusted back to the appropriate PCK component and also validated with two valuators who are experts in the field of analysis and assessment. From the discussion results obtained each of four aspects for each rubric in general but related to the problem of PISA used for analysis of the answer.

Aspects of analysis for rubric assessment of student work consist of the accuracy of the use of mathematical concepts, the accuracy of calculations, identify the steps in solving problems on the problem, and put forward the reasons or ideas. The analytical aspects for rubric assessment of student analysis results consist of assessment of the accuracy of the analysis conducted on the student's work, the ability to understand students' thinking about misconception, the ability to judge according to the rubric, and the recommended strategy/assistance.

\subsection{Test, evaluation, and revision phase}

In this phase, the rubric that developed then tested for prospective teachers in a small group to see their understanding in the problem, readability, and also conformity aspects in rubric. In addition validation by two lecturers as valuators who are experts in the field of analysis and assessment. The validation process is done several times to get the rubric with the right components or aspects of PCK and PISA. Other than it can also be used in general aspect, but not apart from the context or aspects of the rubric.

The validation process is not only on the aspects of PCK that are the focus, but also the context of the PISA solution that will be analyzed and the use of language. In this case also note the capabilities required in solving the problem. In addition, the developed rubric was not only glued specifically on the problem of PISA used in research, but developed to be used in general on mathematics problems. The use of rubric can also be developed by adjusting the problem to be analyzed. The rubric that has been validated and revised can be seen in Table 1 
for the assessment rubric for students and prospective teachers work in solving mathematics problems.

Table 1. Assessment Rubric for Student and Prospective Teacher Work

\begin{tabular}{|c|c|c|c|c|}
\hline Aspects of Analysis & Scale 4 & Scale 3 & Scale 2 & Scale 1 \\
\hline $\begin{array}{l}\text { Appropriateness of } \\
\text { the use of the } \\
\text { mathematical } \\
\text { concept }\end{array}$ & $\begin{array}{l}\text { Using } \\
\text { mathematical } \\
\text { concept is } \\
\text { right and } \\
\text { accordance } \\
\text { with the } \\
\text { overall } \\
\text { problems in } \\
\text { the matter of }\end{array}$ & $\begin{array}{l}\text { Using } \\
\text { mathematical } \\
\text { concept is } \\
\text { precise, but } \\
\text { less suited to a } \\
\text { small fraction } \\
\text { of problems in } \\
\text { the matter of }\end{array}$ & $\begin{array}{l}\text { Using } \\
\text { mathematical } \\
\text { concept is less } \\
\text { precise, but in } \\
\text { accordance } \\
\text { with the } \\
\text { problems in } \\
\text { the matter of }\end{array}$ & $\begin{array}{l}\text { Using } \\
\text { mathematical } \\
\text { concept is less } \\
\text { precise and } \\
\text { does not } \\
\text { correspond } \\
\text { with the } \\
\text { problems in } \\
\text { the matter of }\end{array}$ \\
\hline $\begin{array}{l}\text { Precision of the } \\
\text { calculation of }\end{array}$ & $\begin{array}{l}\text { Whole answer } \\
\text { correctly, } \\
\text { detailed, and } \\
\text { ordered }\end{array}$ & $\begin{array}{l}\text { Whole answer } \\
\text { correctly, but } \\
\text { not detailed } \\
\text { and not } \\
\text { sequential }\end{array}$ & $\begin{array}{l}\text { Most of the } \\
\text { answers } \\
\text { correct, but } \\
\text { less detailed } \\
\text { and not } \\
\text { ordered }\end{array}$ & $\begin{array}{l}\text { Small } \\
\text { percentage of } \\
\text { correct } \\
\text { answers, less } \\
\text { detailed and } \\
\text { not ordered }\end{array}$ \\
\hline $\begin{array}{l}\text { Identifying problems } \\
\text { steps in the matter of }\end{array}$ & $\begin{array}{l}\text { Able to } \\
\text { identify } \\
\text { appropriately } \\
\text { any steps to } \\
\text { resolve the } \\
\text { problems in a } \\
\text { matter of }\end{array}$ & $\begin{array}{l}\text { Being able to } \\
\text { correctly } \\
\text { identify the } \\
\text { majority of } \\
\text { steps to } \\
\text { resolve the } \\
\text { problem in a } \\
\text { matter of }\end{array}$ & $\begin{array}{l}\text { Identify } \\
\text { appropriately } \\
\text { fraction steps } \\
\text { to resolve the } \\
\text { problem in a } \\
\text { matter of }\end{array}$ & $\begin{array}{l}\text { Only identify } \\
\text { known or } \\
\text { asked or part } \\
\text { of the } \\
\text { resolution } \\
\text { process or just } \\
\text { the end result }\end{array}$ \\
\hline $\begin{array}{l}\text { Suggested the reason } \\
\text { or the idea }\end{array}$ & $\begin{array}{l}\text { Wrote all } \\
\text { reason or the } \\
\text { idea of initial } \\
\text { steps to } \\
\text { resolve the } \\
\text { matter until } \\
\text { the end }\end{array}$ & $\begin{array}{l}\text { Wrote largely } \\
\text { the reason or } \\
\text { the idea of } \\
\text { steps to } \\
\text { resolve the } \\
\text { matter }\end{array}$ & $\begin{array}{l}\text { Wrote fraction } \\
\text { reason or the } \\
\text { idea of steps } \\
\text { to resolve the } \\
\text { matter }\end{array}$ & $\begin{array}{l}\text { not write } \\
\text { down the } \\
\text { reasons or the } \\
\text { notion of steps } \\
\text { to resolve the } \\
\text { problem, or } \\
\text { just write } \\
\text { down ideas } \\
\text { end briefly }\end{array}$ \\
\hline
\end{tabular}

\section{Instructions Using the Rubric}

The assessment rubric of students' work is a guide in doing assessment on the completion of mathematics problems. Mathematical problems in the question are a mathematical problem that requires completion with a complete stage that is not only procedurally. Problems can be non-routine questions, mathematics problem form story, PISA, and others.

Every lecturer, teacher and educator who wants to know the ability of learners by analyzing their work in solving the problem can use the guidance of this assessment rubric. This is because the aspect of analysis on the rubric is an aspect in general so that it can be used by everyone in analyzing the problem solving especially mathematics problems. In this rubric the score or value for each aspect of the analysis is the same is one because all aspects have the same part. 
To analyze, take into consideration all aspects of the answer. Then focus on four aspects of the existing analysis.

1. Aspect of analysis: The accuracy of the use of mathematical concepts.

The mathematical concept in the question is the accuracy in the use of the formula in accordance with the problem on the problem.

2. Aspect of analysis: Accuracy of calculation.

The calculation is not only the end result but also the calculations performed on each problem solving step. In addition, not only the result of counting in the form of numbers but also the accuracy of the units used.

3. Aspects of analysis: Identify the steps in solving the problem on the problem.

Provide assessment for each step done in solving the problem in accordance with the problem on the question.

\section{Aspects of analysis: Suggests reasons or ideas}

Problem solving is not only done procedurally but also provides reason and introduction on every step of the settlement and makes conclusions for the final results in accordance with the problem on the problem.

Guidelines assessment rubric on the analysis of prospective teacher for students' works used by researcher based PCK components can be seen in Table 2.

Based on the research of [14] that to know the analysis of the ability of prospective teachers in analyzing students' understanding can be used the results of student work which is the result of student thinking. This is in accordance with research conducted using student's work. Therefore, according to [15] that prospective teacher can develop their understanding better for students' thinking if they take time to discuss about meaning of concepts, relationships, common conceptions, and student's difficulties.

Table 2. Assessment Rubric for the Result of Prospective Teachers' Analysis

\begin{tabular}{|c|c|c|c|c|}
\hline $\begin{array}{l}\text { Aspects of } \\
\text { analysis }\end{array}$ & Scale 4 & Scale 3 & Scale 2 & Scale 1 \\
\hline $\begin{array}{l}\text { Rating } \\
\text { accuracy of } \\
\text { the analysis } \\
\text { conducted to } \\
\text { students' } \\
\text { work }\end{array}$ & $\begin{array}{l}\text { Assessing all } \\
\text { aspects of } \\
\text { analysis with } \\
\text { appropriate }\end{array}$ & $\begin{array}{l}\text { Assessing } \\
\text { most aspects } \\
\text { of analysis } \\
\text { with } \\
\text { appropriate }\end{array}$ & $\begin{array}{l}\text { Assessing the } \\
\text { few aspects } \\
\text { of analysis } \\
\text { with } \\
\text { appropriate }\end{array}$ & $\begin{array}{l}\text { Assessing } \\
\text { less precise } \\
\text { every aspect } \\
\text { of analysis }\end{array}$ \\
\hline $\begin{array}{l}\text { Ability to } \\
\text { understand } \\
\text { students' } \\
\text { thinking } \\
\text { about the } \\
\text { misconceptio } \\
\text { ns }\end{array}$ & $\begin{array}{l}\text { Able to } \\
\text { recognize and } \\
\text { understand } \\
\text { any } \\
\text { misconceptio } \\
\text { ns of student } \\
\text { work }\end{array}$ & $\begin{array}{l}\text { Able to } \\
\text { recognize } \\
\text { most of the } \\
\text { misconceptio } \\
\text { ns of student } \\
\text { work } \\
\text { accurately }\end{array}$ & $\begin{array}{l}\text { Able to } \\
\text { recognize a } \\
\text { small portion } \\
\text { misconceptio } \\
\text { ns of students } \\
\text { work } \\
\text { accurately }\end{array}$ & $\begin{array}{l}\text { Able to } \\
\text { recognize a } \\
\text { small portion } \\
\text { misconceptio } \\
\text { ns of student } \\
\text { work but not } \\
\text { exactly }\end{array}$ \\
\hline
\end{tabular}




\begin{tabular}{|c|c|c|c|c|}
\hline $\begin{array}{l}\text { Aspects of } \\
\text { analysis }\end{array}$ & Scale 4 & Scale 3 & Scale 2 & Scale 1 \\
\hline & accurately & & & \\
\hline $\begin{array}{l}\text { Ability to } \\
\text { give an } \\
\text { assessment } \\
\text { based on } \\
\text { rubric }\end{array}$ & $\begin{array}{l}\text { Able to } \\
\text { provide an } \\
\text { assessment } \\
\text { for all aspect } \\
\text { appropriately }\end{array}$ & $\begin{array}{l}\text { Able to } \\
\text { provide an } \\
\text { assessment of } \\
\text { most aspects } \\
\text { appropriately }\end{array}$ & $\begin{array}{l}\text { Able to } \\
\text { provide an } \\
\text { assessment of } \\
\text { the few } \\
\text { aspects } \\
\text { appropriately }\end{array}$ & $\begin{array}{l}\text { Able to } \\
\text { provide an } \\
\text { assessment of } \\
\text { the few } \\
\text { aspects but } \\
\text { not exactly }\end{array}$ \\
\hline $\begin{array}{l}\text { Precision of } \\
\text { the strategy / } \\
\text { assistance } \\
\text { recommended }\end{array}$ & $\begin{array}{l}\text { Suggest aid / } \\
\text { strategy } \\
\text { appropriate to } \\
\text { the whole } \\
\text { thing on a } \\
\text { matter }\end{array}$ & $\begin{array}{l}\text { Suggest aid / } \\
\text { strategy just } \\
\text { right for most } \\
\text { of the } \\
\text { problems on a } \\
\text { matter }\end{array}$ & $\begin{array}{l}\text { Suggest aid / } \\
\text { strategy just } \\
\text { right for a } \\
\text { small fraction } \\
\text { of problems } \\
\text { on a matter }\end{array}$ & $\begin{array}{l}\text { Suggest aid / } \\
\text { strategy but it } \\
\text { is not } \\
\text { appropriate } \\
\text { and does not } \\
\text { correspond } \\
\text { with the } \\
\text { problems on a } \\
\text { matter }\end{array}$ \\
\hline
\end{tabular}

\section{Instructions Using the Rubric}

Assessment rubric of the results of prospective teacher's analysis is a guide in assessing the results of analysis conducted by prospective teachers to students' work in solving nonroutine problems which in this case is PISA questions.

Every lecturer, teacher and educator who wants to know the ability of learners in their analysis can use the guidelines of this assessment rubric. This is because the aspect of analysis on the rubric is an aspect in general so that it can be used by everyone in analyzing and assessing the results of the analysis performed. In this rubric the score or value for the first analysis aspect is two because it is considered to have a large part in the analysis whereas the value for the other three aspects are the same is one because the three aspects have the same part.

To conduct the assessment, the overall aspects of the analysis are considered. Then focus on four aspects of the existing analysis.

1. Aspect of analysis: Assessment of the accuracy of the analysis conducted on students' work

The accuracy of the analysis in the problem is the overall aspects of analysis in analyzing students' work, such as the four aspects of the previous analysis on the guidelines assessment rubric of students and prospective teachers work.

2. Aspect of analysis: Ability to understand students' thinking about misconception

In analyzing the students' work, they also pay attention to the misconception and difficulties experienced by the students in solving the problem. 
3. Aspect of analysis: The ability to judge according to the rubric

Provide an assessment of the assessment of student work by taking into account every aspect of analysis and assessment appropriately.

4. Aspect of analysis: The accuracy of the strategy / assistance provided

This aspect is an additional aspect. Used if the analysis and assessment conducted for the results of the analysis of the work of the students demanded assistance advice in overcoming students' difficulties in solving the problem.

\section{Conclusions}

The both rubrics have a valid criteria consisting of content validity and construct validity. Content validity is viewed based on the suitability of material and concept for PISA questions with thinking level of junior high school students and prospective teachers. Construct validity was viewed based on the suitability of aspects at rubrics with concept of PISA questions and PCK components, and presentation of analysis aspects in rubric structurally.

\section{References}

[1] Organisation for Economic Co-operation and Development (OECD), "PISA 2009 Assessment Framework: Key Competencies in Reading, Mathematics and Science," OECD Publ., p. 292, 2010.

[2] L. S. Grønmo and R. V. Olsen, "Timss Versus Pisa : the Case of Pure and Applied," pp. 1-16, 2004.

[3] R. Sulastri, R. Johar, and S. Munzir, "Kemampuan Mahasiswa Program Studi Pendidikan Matematika FKIP Unsyiah Menyelesaikan Soal PISA Most Difficult Level," J. Didakt. Mat., vol. 1, no. 2, pp. 13-21, 2012.

[4] Organisation for Economic Co-operation and Development (OECD), "PISA 2012 Results in Focus; What 15-Year-Olds Know and What They Can Do with What They Know.," 2013.

[5] Organisation for Economic Co-operation and Development (OECD), "PISA 2015 Results in Focus," 2016.

[6] T. Tambychik and T. S. M. Meerah, "Students' difficulties in mathematics problemsolving: What do they say?," Procedia - Soc. Behav. Sci., vol. 8, no. 5, pp. 142-151, 2010.

[7] P. Phonapichat, S. Wongwanich, and S. Sujiva, "An Analysis of Elementary School Students' Difficulties in Mathematical Problem Solving," Procedia - Soc. Behav. Sci., vol. 116, no. 2012, pp. 3169-3174, 2014.

[8] Z. Bayrakdar, D. Deniz, L. Akgün, and T. Isleyen, "Problem solving approaches of mathematics teacher candidates in PISA 2003," Procedia - Soc. Behav. Sci., vol. 15, no. 0, pp. 3334-3337, 2011.

[9] M. A. Sorto, J. H. Marshall, T. F. Luschei, and M. Carnoy, "Teacher Knowledge and Teaching in Panama and Costa Rica: A Comparative Study in Primary and Secondary 
Education," Rev. Latinoam. Investig. en Mat. Educ., vol. 12, no. 2, pp. 251-290, 2009.

[10] T. Plomp, "Educational Design Research: an Introduction," in An Introduction to Educational Design Research, 2007, p. 19.

[11] M. Baker and H. Chick, "Pedagogical Content Knowledge for Teaching Primary Mathematics: A Case Study of Two Teachers," P. Grootenboer, R. Zevenbergen M. Chinnappan (Eds), Identities, Cult. Learn. Spaces Proc. 29th Annu. Conf. Math. Educ. Res. Gr. Australas. Canbaerra MERGA, vol. 1, pp. 60-67, 2006.

[12] H. P. Koirala, M. Davis, and P. Johnson, "Development of a performance assessment task and rubric to measure prospective secondary school mathematics teachers' pedagogical content knowldege and skills," J. Math. Teach. Educ., vol. 11, no. 1, pp. 127-138, 2008.

[13] F. Depaepe, L. Verschaffel, and G. Kelchtermans, "Pedagogical content knowledge: A systematic review of the way in which the concept has pervaded mathematics educational research," Teach. Teach. Educ., vol. 34, pp. 12-25, 2013.

[14] S. M. Spitzer, C. M. Phelps, J. E. R. Beyers, D. Y. Johnson, and E. M. Sieminski, "Developing prospective elementary teachers' abilities to identify evidence of student mathematical achievement," J. Math. Teach. Educ., vol. 14, no. 1, pp. 67-87, 2011.

[15] M. Isiksal and E. Cakiroglu, "The nature of prospective mathematics teachers ' pedagogical content knowledge: the case of multiplication of fractions," J. Math. Teach. Educ., vol. 14, no. 1, pp. 213-230, 2011. 